\title{
Scientific Production Indexed in the Web of Science Basis in the Energy Management Area: A Bibliometric Analysis
}

\author{
Edenis Cesar de Oliveira ${ }^{1}$, Nilton Cezar Carraro ${ }^{1}$ \\ ${ }^{1}$ Business School with Training Line in Agroindustrial Systems, Federal University of São Carlos - UFSCar, \\ São Paulo, Brazil \\ Correspondence: Natural Sciences Center, Federal University of Sao Carlos - UFSCar/CCN-LS, Rua Serafim \\ Libaneo 04, CP 64, Centro, 18245-000, Campina do Monte Alegre - Sao Paulo, Brazil.
}

Received: November 22, 2019

doi:10.5539/ibr.v13n1p206
Accepted: December 13, 2019 Online Published: December 19, 2019

URL: https://doi.org/10.5539/ibr.v13n1p206

\begin{abstract}
The study aimed to analyze publications in the field of energy management study. To this end, a search was carried out on the Web of Science from 1999 to 2019, searching for articles that contained in its title the keyword "Energy Manag*". After filtering all documents, excluding those presented at conferences, 5,512 documents were obtained. We chose to analyze only documents in the "articles" mode, leaving a total of 4,610. From 2007 the growth was quite significant in the number of publications. There is a predominance of the English language. Of the top ten authors with the largest number of publications, six are linked to educational / research institutions located in China, which also ranks first in the ranking of countries with the highest number of publications. "Energies", "Applied Energy" and "Energy" journals rank first, second and third respectively. The h-index index of publications is 111 , while the h-index index of the ten best-ranked authors is 40 . When compared to other studies with relative similarity, there is exponential growth in China, both number of publications, and authors linked to Chinese institutions, which, it is believed, should be the trend for the next years in this and other fields of study.
\end{abstract}

Keywords: energy management, bibliometrics, h-index, energy efficiency, impact factor

\section{Introduction}

Aspects of sustainability have increasingly been presented as a strategic and guiding element in the formation of economic policies practiced in many countries around the world. In this context, a policy that aims to underpin sustainable development necessarily presupposes the efficient use of energy resources. Energy is considered a key factor for development (Sepúlveda 2016) and an important element contributing to the achievement of a world economy (Zhenxing and Jing 2007). According to the International Energy Agency, the development of effective actions becomes important to solve problems related to climate change in the energy sector (IEA, 2015; Cristino et al. 2018).

Accordingly, with the recognition of importance and availability of technologies for the alternative energy, the associated body of literature has grown substantially. The research related to the alternative energy has become multidisciplinary covering a wide spectrum (Guozhu et al. 2015). Furthermore, energy management is becoming a priority as organizations strive to reduce energy costs, conform to regulatory requirements, and improve their corporate image (Antunes et al. 2014).

The most serious concern with Energy Efficiency (EE) arose as a consequence of the oil shocks of 1973-74 and 1979-81 that brought the perception of scarcity of this energy resource, forcing the prices of this and other resources, allowing a series of conservation actions and greater efficiency in the use of its derivatives. During this same period, a race began to diversify the energy matrix, aiming at greater security in meeting energy demand. An emblematic example in Brazil was the case of Proálcool in the mid-1970s (MME, 2011).

The National Energy Efficiency Plan (PNEF) notes that, since the publication of the Club of Rome studies, in addition to the movements for the benefit of the environment, in addition to the treaties related to climate change, EE has been elevated to the condition of strategic instrument and sometimes preferable for mitigating greenhouse gas (GHG) emissions and ozone depleting effects.

Lafontaine et al. (2010) corroborate this assertion by highlighting the growing interest of the world 
academic-scientific community in the theme of Energy Efficiency as a way to act directly in the reduction of GHG, contributing to the mitigation of climate change on the planet. Thus, increased efficiency can be one of the most economically and environmentally friendly ways to meet part of the energy requirements.

The case of China is emblematic. Since reforms including the economic opening in 1978, the country has achieved rapid economic growth, and its overall economy now ranks second in the world (Zhang and Yang, 2013). As a result, it also consumes a lot of energy and discharges a large number of pollutants into the ecosystem (Zhang et al., 2008). For this reason, the Chinese government has been obliged to pay more attention to the development of low carbon energy (Huang et al. 2012). Nuclear power is one of the measures available to meet new energy demands. On the one hand, nuclear power can reduce China's carbon emissions and secure the energy supply. On the other hand, nuclear power has certain safety risks and requires higher safety technologies. To this end, the Chinese government has enacted a series of policies to support the development of nuclear energy and ensure its safe implementation (Huang et al. 2018). Energy efficiency policy is considered as a strategic activity by most policy makers (Filippini and Hunt, 2015). Most countries have energy efficiency policies, such as promoting the use of new energy and funding energy research (Du et al. 2018).

For Oikonomou et al. (2009) energy efficiency is linked to the adoption of a specific technology capable of reducing energy consumption without behavioral change, while the term energy conservation is directly linked to consumer behavioral change. Croucher (2011) postulates that the achievement of energy efficiency is given by the relationship between the energy actually consumed and the energy demanded, while energy conservation is obtained by minimizing the use of energy-consuming goods and services, such as equipment connected in standy-by, for example.

Energy efficiency corresponds to the implementation of measures that reduce the energy required to meet society's demands for energy services. In short, meeting the needs of the economy with the lowest possible expenditure of primary energy and thus with the least impact on the environment.

Actions aimed at energy efficiency include modifications and / or insertion of technologies that improve the process of production, distribution and use of energy, and may also result from better organization, conservation and energy management by the system's component institutions (Birth, 2015). Energy Efficiency can be worked on at various levels and scales, whether regarding land use planning policies, companies or even the domestic consumer level (Carvalho, 2013). Policy makers, business leaders, consumers and researchers have increasingly turned their attention to the alternative energy sources such as solar, wind, and biomass (Narayanana and Natarajanb, 2007; Patrik and Thomas, 2007; Gustav et al. 2008; Kern and Smith, 2008, Zhao et al. 2009; Zhao et al. 2011). Therefore, it is necessary to evaluate the growing body of literature on the alternative energy. Bibliometric techniques can offer an important quantitative perspective to assess the development and growth of research related to the alternative energy (Guozhu et al. 2015).

Given the above, this paper aims to investigate the scenario of publications on the Web of Science database of the Institute for Scientific Information (ISI) whose papers have in their title the keyword "energy management" in the period between 2006 and 2019.

\section{Method}

A traditional literature review was performed as a fundamental part to support the construction of the text, especially the discussion of the results. Literature review is a totally essential approach in building the basis for any scientific investigation, being crucial to define and justify the research design, objective or methodology (Hart, 1998). Drawing on Fink (2005), May et al. (2017) point out the importance of literature review as the main approach for the identification and systematic evaluation of pertinent knowledge about a particular research subject. Therefore, the literature review serves the purpose of investigating and evaluating the existing set of knowledge in a given field and identifying possible research gaps (Tranfield et al., 2003).

It is known that the process of scientific research starts from a problem, which can be a question or a doubt, which motivates researchers to seek information on a particular theme in libraries and digital bibliographic databases (Tasca et al. 2010). Bibliometrics is a straightforward analytical approach to measuring and evaluating a large number of scientific publications and citations (Ismail et al., 2009).

As for the more general objectives, the present study is classified as descriptive (Hair et al. 2005; Gil, 2010), using bibliometric analysis, mainly due to the nature of its exploratory investigation, with a view to describing the amount, main characteristics and productivity of international scientific publications on a particular topic of growing interest in the academic-scientific community. As for the approach, it is characterized as quantitative. According to Richardson et al. (1999, p. 70), "the quantitative method [...] is characterized by the use of 
quantification both in the mode of information collection and in their treatment through statistical techniques [...]". Cardoso et al. (2005) understand that analyzing academic works from the mapping of a given area through systematic reviews is an important way to allow evaluative and reflective processes of these works, as well as the area in question.

Bibliometrics is a useful set of methods for quantitatively analyzing scientific and technological literature (De Bellis, 2009). It was defined as "the application of mathematics and statistical methods to books and other media (Pritchard, 1969). There are two most common bibliometric methods: citation analysis and content analysis. Bibliometric methods have been widely employed to investigate the impact of research fields, the impact of scholars, and the impact of a specific publication (Henderson et al. 2009). The bibliometric technique is mainly qualitative, transforming something intangible (scientific quality) into a manageable entity. It was widely adopted in quantitative research exercises of academic production. Two advantages associated with bibliometric analysis are: i. it uses indicators and the calculation of certain classical laws to evaluate research or scientific output in a specific area over a period of time; ii. offers an assessment approach that recognizes the nature of science's knowledge generation as a system (Du et al. 2013). In fact, bibliometric techniques have become an indispensable instrument for measuring scientific progress in various fields.

Scientific communication, seen as an integrated set of various activities / actions related to the publicization and use of information, constitutes an important factor that enables the acceptance of official academic production as part of scientific knowledge.

Regarding the procedures, it is classified as bibliographic research, since it proposes to conduct a survey of the scientific production on "energy management". In the conception of Raupp and Beuren (2008, p. 87) in this typology "the material consulted in the bibliographic research covers all references already made public regarding the subject of study, from loose publications, newsletters, newspapers, magazines, books, research, monographs, dissertations, theses, among others".

Longitudinal bibliometric research has been common in the Brazilian-academic literature (Perin et al. 2000; Vieira, 2003; Campomar, 2005; Venuto and De Muylder, 2010). Bibliometric research or desk research, in the context of international academic production, makes major contributions to the literature review process, notably by listing the main articles, authors and current lines of research on a given field of research globally.

A bibliometric analysis consists of applying statistical methods to determine qualitative and quantitative changes in a given scientific research topic, profile publications on the topic, and detect trends within a discipline (De Bakker, Groenewegen and Den Hond, 2005). In addition, this type of analysis provides useful information for specialists seeking to evaluate scientific activity (Duque, Cervera and Rodríguez, 2006), as bibliometric analysis for this particular case acts as a guide to the status of energy management research.

\section{Characteristics of Publications}

The data for this study were extracted from the Web of Science (WoS) database (Merigó et al. 2015), of the Institute for Scientific Information (ISI) - Clarivate Analytics - considered one of the largest companies in the scientific knowledge diffusion segment. WoS is a multidisciplinary database that indexes only the most cited journals in their respective fields. The following subsection will present the most detailed collection procedures and, later, the data analysis. Figure 1 schematically presents the methodological design of the first phase of the research.

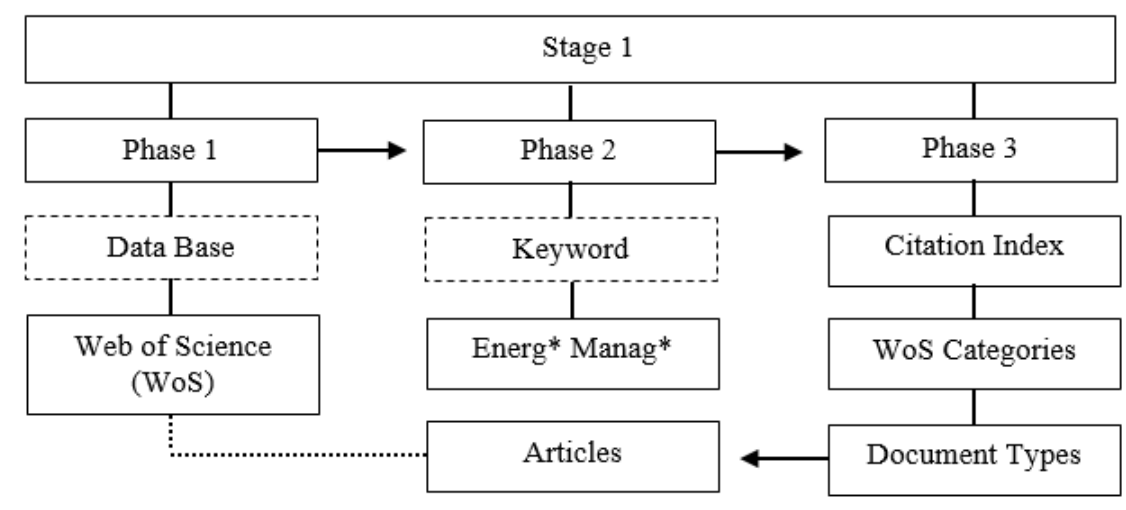

Figure 1. Methodological design of the first phase of the research 


\subsection{Wos Collections Included and Excluded From Study Clipping}

The Web of Science (WoS) was searched for documents containing the keyword "Energ* Manag*" (energy management) in its title. The insertion of the asterisk after each word signals to the base search engine a "truncation" (Cooper and Schindler, 2016). This will only search for documents that contain the exact keyword as entered. In addition, the Citation Index criterion was followed from the WoS Collection, as shown in Table 1.

Table 1. Web of Science collection included / excluded from initial research

\begin{tabular}{llcc}
\hline Web of Science Collection $(\mathbf{W o S})$ & Initials & Doc & Situation \\
\hline Science Citation Index Expanded & SCI-EXPANDED & 4,965 & Included \\
Social Sciences Citation Index & SSCI & 601 & Included \\
Arts \& Humanities Citation Index & A\&HCI & 15 & Included \\
Conference Proceedings Citation Index - Science & CPCI-S & 304 & Excluded \\
Conference Proc Citation Index - Social Science \& Humanities & CPCI-SSH & 4 & Excluded \\
Emerging Sources Citation Index & ESCI & 406 & Included \\
\hline
\end{tabular}

From the Web of Science Index set, composed of six collections, two were excluded from the citations made in Conference Proceedings, representing $4.89 \%$ of the total. This procedure was necessary to maintain the criterion of analyzing only journal publications, thus excluding those from event annals.

\subsection{Year of Publication}

Once the longitudinal cut (1999-2019) was established, 5,512 articles were obtained. Once this first set of criteria was established, within the Web of Science platform, document types were restricted to "articles" only, leaving an amount of 4,610 articles. Figure 2 shows the number of articles published for each year of the established period.

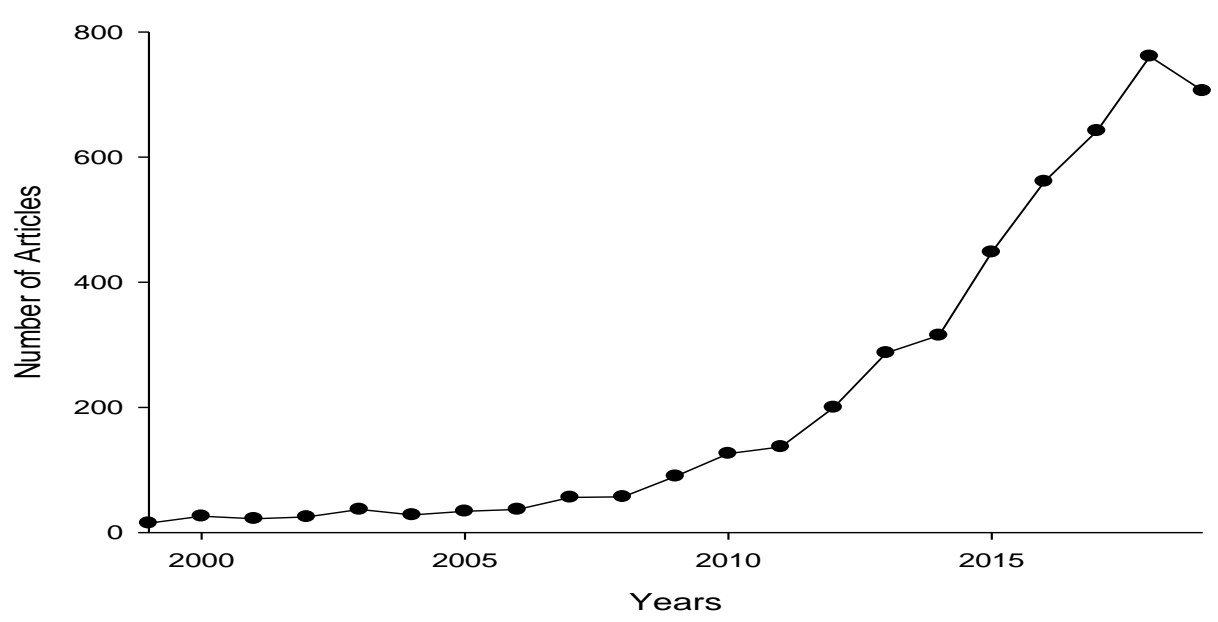

Figure 2. Number of articles published in the established period

Data extracted from the platform for this study was performed in mid-November 2019, so it is believed that by the end of this year other publications may be available. Nevertheless, there is a significant increase in the number of publications in these two decades, in the order of more than 4,600\%. In the period from 1999 to 2006 , the average number of articles published was of the order of twenty-eight (28) articles, representing, in percentage terms, $0.607 \%$ of the articles of this period. From 2007 onward a very significant growth curve was established, culminating in seven hundred and sixty-one (761) articles published in 2018, representing over 16\% of the total of this period (2007 - 2018), data corroborated by previous study (Guozhu et al. 2015).

There is an indicative scenario that studies in the area of energy, more precisely, energy management, are directly related to the growth of the demand of energy itself, especially by emerging countries, which is considered a 
basic and essential ingredient for the development of a nation (Goldemberg, 2000).

Publications have been increasing in the number of authors per article, which can be considered a unique phenomenon in recent decades worldwide (Camargo Jr. and Coeli, 2012). Such an occurrence can be corroborated by other international studies (Epstein, 1993; Levsky et al., 2007; Baethge, 2008; Shaban and Aw, 2009). The research by Wuchty et al. (2007) verified the authorship of thousands of articles over 50 years, showing that this phenomenon occurs in all areas of knowledge, including the social sciences, although with less intensity.

\subsection{Language}

The number of publications in the English language is predominant, comprising almost $98 \%$ of all publications, very close to that found by Ghozhu et al (2015), in the order of $95.73 \%$. Articles published in Portuguese occupy the fourth position in the ranking, representing $0.312 \%$ of publications in English. Table 2 presents the ten predominant languages in the publications.

Table 2. Top article publishing languages

\begin{tabular}{lcc}
\hline Language & Records & \% of 4,610 \\
\hline English & 4,491 & 97,419 \\
German & 34 & 0,738 \\
Spanish & 34 & 0,738 \\
Portuguese & 14 & 0,304 \\
Russian & 11 & 0,239 \\
Polish & 10 & 0,217 \\
French & 8 & 0,174 \\
Turkish & 5 & 0,108 \\
Japanese & 2 & 0,043 \\
Dutch & 1 & 0,022 \\
\hline
\end{tabular}

Another important fact seen in the verification of the languages refers to the fact that the Spanish language presents the same amount of publications of the German language. This corroborates the fact that the English language is the most widely used in the dissemination of scientific research followed, as it were, by the Spanish language.

Even so, the difference between the number of publications in the English language and the number of publications in the Spanish language is 96,680 percentage points, showing that there is a significant difference with total predominance of English.

Other studies corroborate the predominance of the English language in publications in the field of study: Du et al. (2013), 95.5\% of English publications in a sample of 8,244 publications (period 1991 - 2010); Chen et al. (2016), 99.96\% of English publications for a total of 19,759 documents in the period 1993-2012.

\subsection{WoS Categories}

Of this set of documents (articles), only WoS categories with a percentage equal to or greater than $1 \%$ were maintained. Applying this filter, the total volume of papers dropped to 3,809, distributed as shown in Table 3 . 
Table 3. Web Base of Science categories with percentage over $1 \%$ and their publication quantities

\begin{tabular}{|c|c|c|c|}
\hline Order & WoS Categories & Records & $\%$ of 3,809 \\
\hline 1 & Energy Fuels & 1391 & 36.519 \\
\hline 2 & Engineering Electrical Electronic & 1251 & 32.843 \\
\hline 3 & Telecommunications & 437 & 11.473 \\
\hline 4 & Green Sustainable Science Technology & 388 & 10.186 \\
\hline 5 & Environmental Sciences & 380 & 9.976 \\
\hline 6 & Thermodynamics & 372 & 9.766 \\
\hline 7 & Computer Science Information Systems & 335 & 8.795 \\
\hline 8 & Engineering Chemical & 244 & 6.406 \\
\hline 9 & Automation Control Systems & 242 & 6.353 \\
\hline 10 & Construction Building Technology & 205 & 5.382 \\
\hline 11 & Engineering Environmental & 198 & 5.198 \\
\hline 12 & Transportation Science Technology & 168 & 4.411 \\
\hline 13 & Engineering Civil & 166 & 4.358 \\
\hline 14 & Mechanics & 165 & 4.332 \\
\hline 15 & Computer Science Hardware Architecture & 163 & 4.279 \\
\hline 16 & Environmental Studies & 152 & 3.991 \\
\hline 17 & Engineering Mechanical & 130 & 3.413 \\
\hline 18 & Computer Science Interdisciplinary Applications & 126 & 3.308 \\
\hline 19 & Computer Science Theory Methods & 106 & 2.783 \\
\hline 20 & Instruments Instrumentation & 99 & 2.599 \\
\hline 21 & Materials Science Multidisciplinary & 96 & 2.520 \\
\hline 22 & Engineering Industrial & 95 & 2.494 \\
\hline 23 & Economics & 92 & 2.415 \\
\hline 24 & Computer Science Software Engineering & 89 & 2.337 \\
\hline 25 & Chemistry Physical & 85 & 2.232 \\
\hline 26 & Electrochemistry & 82 & 2.153 \\
\hline 27 & Engineering Multidisciplinary & 81 & 2.127 \\
\hline 28 & Computer Science Artificial Intelligence & 68 & 1.785 \\
\hline 29 & Physics Applied & 54 & 1.418 \\
\hline 30 & Chemistry Multidisciplinary & 47 & 1.234 \\
\hline 31 & Operations Research Management Science & 47 & 1.234 \\
\hline 32 & Water Resources & 47 & 1.234 \\
\hline 33 & Management & 45 & 1.181 \\
\hline
\end{tabular}

The criterion of adopting categories with values equal to or greater than $1 \%$ allowed to narrow the search to those presented in Table 3, which, as noted, tops the list of "Renewable Fuels" with more than one third of the total and, at the "Management" category with approximately 1.2\%. Coincidental or not, the list begins and ends containing the two key expressions used in the initial search, a fact that corroborates the consistency of the preliminary data verification.

\subsection{Financing Agencies}

As for the Financing Agencies, the same criterion was chosen, with only those with a percentage volume higher 
than $1 \%$. Three more well-known Brazilian agencies were added, with their respective records and percentage. It should also be noted that, after the definition of the Financing Agencies, the volume of articles decreased to 1,829. Table 4 shows these categories with their records and percentages.

Table 4. Financing Agencies with their records and percentages

\begin{tabular}{lcc}
\hline Financing Agencies & Records & \% of 1829 \\
\hline National Natural Science Foundation of China & 84 & 4,593 \\
National Science Foundation NSF & 55 & 3,007 \\
European Union EU & 26 & 1,422 \\
Engineering Physical Sciences Research Council EPSRC & 20 & 1,093 \\
Fundamental Research Funds for The Central Universities & 20 & 1,093 \\
Brazilian National Council for Scientific and Technological Development CNPQ & 1 & 0,055 \\
Paulista Power and Light Company CPFL & 1 & 0,055 \\
Sao Paulo State Research Support Foundation FAPESP & 1 & 0,055 \\
Others & 1621 & 88,628 \\
\hline
\end{tabular}

Of the three Brazilian agencies, two are public and one is publicly traded and privately held (CPFL). There is a lack of investment in this area of research by Brazilian funding agencies.

The "Other" category containing 1,621 records refers to funding agencies with only one record, so they were merged into a single category. "Spraying" seems to be a hallmark of all funded studies. Thus, we reinforce the thesis that the first five listed have very expressive numbers. Another important feature concerns the country of origin of the funding agencies. Table 5 shows the country to which each agency originates.

Table 5. Financing Agencies and their respective countries of origin

\begin{tabular}{ll}
\hline Financing Agencies & Country / Origin \\
\hline National Natural Science Foundation of China & China \\
National Science Foundation NSF & United States \\
European Union EU & European Union \\
Engineering Physical Sciences Research Council EPSRC & United Kingdom \\
Fundamental Research Funds for The Central Universities & China \\
\hline
\end{tabular}

Studies have pointed to the need for investment in this field of research. In this sense, countries such as the United States, China, as well as the European Union, have stood out in this regard, corroborating studies already carried out (Zhang and Yang 2013; Du et al. 2018).

\subsection{Authors}

The ten authors with the largest number of published articles account for $4.16 \%$ of the total publications $(4,610)$. The remaining 4,418 papers appear distributed in 12,361 other authors, with an overall average of 2.8 authors per published article. Table 6 presents the ten authors ranked by production volume. Information on the authors' institutional links was obtained from Research Gate's main Scholar homepage, which is matched by the information entered by the authors directly into their most recent publications. 


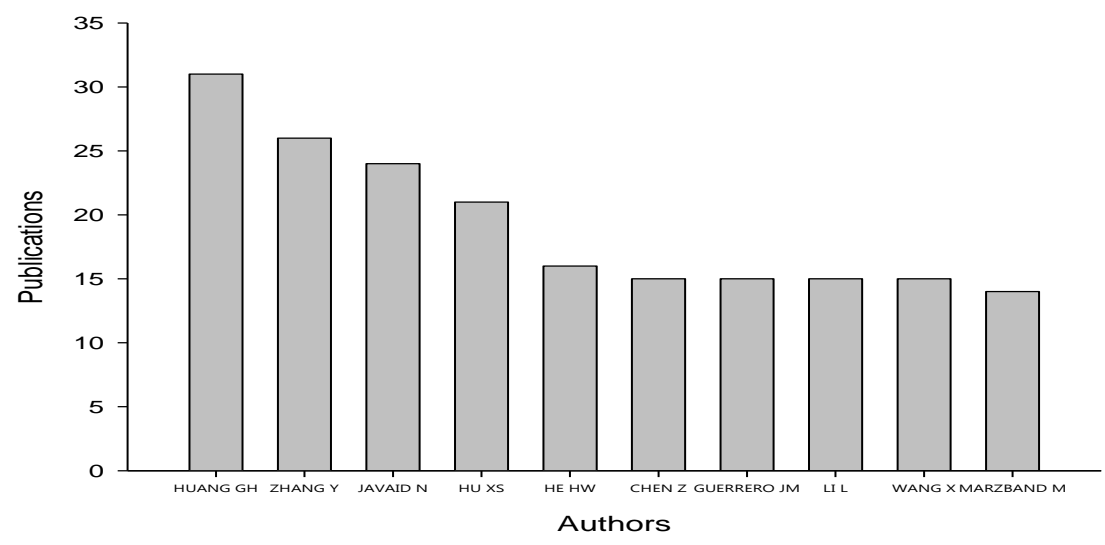

Figure 3. Authors and their publication numbers

Table 6. Author ranking, publications and institutional links

\begin{tabular}{|c|c|c|c|c|c|c|}
\hline Ranking & Authors & Records & $\begin{array}{l}\% \text { of } \\
4,610\end{array}$ & Institution & Country & $h$-index \\
\hline 1 & Huang GH & 31 & 0,672 & $\begin{array}{l}\text { School of Control and Computer } \\
\text { Engineering }\end{array}$ & China & 12 \\
\hline 2 & Zhang Y & 26 & 0,564 & $\begin{array}{l}\text { School of Mechanical and Aerospace } \\
\text { Engineering Queen's University Belfast }\end{array}$ & UK & 13 \\
\hline 3 & Javaid N & 24 & 0,521 & COMSATS University & Pakistan & 10 \\
\hline 4 & Hu XS & 21 & 0,456 & Chongqing University & China & 13 \\
\hline 5 & He HW & 16 & 0,347 & $\begin{array}{l}\text { National Engineering Laboratory for } \\
\text { Electric Vehicles }\end{array}$ & China & 8 \\
\hline 6 & Chen Z & 15 & 0,325 & $\begin{array}{l}\text { Faculty of Transportation Engineering } \\
\text { Kunming University of Science and } \\
\text { Technology }\end{array}$ & China & 8 \\
\hline 7 & $\begin{array}{l}\text { Guerrero } \\
\text { JM }\end{array}$ & 15 & 0,325 & $\begin{array}{l}\text { Institute of Energy Technology, Aalborg } \\
\text { University }\end{array}$ & Denmark & 8 \\
\hline 8 & $\mathrm{Li} \mathrm{L}$ & 15 & 0,325 & School of Mechanical Engineering & China & 7 \\
\hline 9 & Wang X & 15 & 0,325 & Tianjin University (TJU) & China & 10 \\
\hline 10 & $\begin{array}{l}\text { Marzband } \\
\text { M }\end{array}$ & 14 & 0,304 & Northumbria University Newcastle & UK & 12 \\
\hline
\end{tabular}

Sixty percent of the authors listed in the top ten most published are linked to some teaching / research institution located in China, corroborated by the data listed in Table 8 where China ranks first among the ten countries with more publications. The average h-index (h-index $\mathrm{m}_{\mathrm{m}}$ ) of the ten most successful authors in publication is 10.1. Tianjin University (TJU) research / education institution ranks eighth in the research undertaken by Chem et al. (2016), while Aalborg University in Denmark appears in tenth position in the study by Guozhu et al. (2015).

Table 7 presents information on total publications, sum of citations, sum of citations without self-citations, cited articles, articles cited without self-citations, average citation per item, and the h-index index for the ten authors with the highest number of publications. When compared to the general table of publications (Table 10), it is observed that the ten authors with the largest number of publications have $3.948 \%$ of the total volume of articles published in the period $(4,610)$. On the other hand, the $\mathrm{h}$ index of this same set of authors represents approximately one third $(36.03 \%)$ of the total $\mathrm{h}$ index. 
Table 7. Web of Science - WoS Core Collection Report for Top 10 Authors

\begin{tabular}{ccccccc}
\hline $\mathbf{1}$ & $\mathbf{2}$ & $\mathbf{3}$ & $\mathbf{4}$ & $\mathbf{5}$ & $\mathbf{6}$ & $\mathbf{7}$ \\
\hline $\begin{array}{c}\text { Total } \\
\text { publications }\end{array}$ & $\begin{array}{c}\text { Sum of } \\
\text { citations }\end{array}$ & $\begin{array}{c}\text { Sum of } \\
\text { citations } \\
\text { without } \\
\text { self-citations }\end{array}$ & $\begin{array}{c}\text { Articles that } \\
\text { cited }\end{array}$ & $\begin{array}{c}\text { Articles that } \\
\text { cited without } \\
\text { self-citations }\end{array}$ & $\begin{array}{c}\text { Average } \\
\text { citations per } \\
\text { item }\end{array}$ & h-index \\
\hline 182 & 5,269 & 4,932 & 3,605 & 3,500 & 28,95 & 40 \\
\hline
\end{tabular}

Of the ten authors with the highest number of citations, $60 \%$ are linked to institutions whose home country is China, followed by the United Kingdom, Pakistan and Denmark. Figure 3 graphically represents the information contained in Table 6.

\subsection{Countries}

The ten countries with the highest number of publications are listed in Table 8. Together, these countries account for $81.32 \%$, a total volume of 3,749 publications. Brazil occupies the 22nd position in the ranking behind Germany, Australia, Japan, Taiwan, Greece, Turkey, Sweden, the Netherlands, Portugal, Pakistan and Singapore.

Although the research chaired by Guozhu et al. (2015) was carried out in the period 1994-2013, using the keywords "renewable energ*" and "sustainable energ*" that appeared in the title, abstract and keyword, in a universe of 14,902 publications, the United States leads the ranking followed by the United Kingdom. China appears in fourth place and Spain in sixth.

This expressive growth in publications from educational / research institutions located in China is believed to reflect the public investment policy implemented by the country in recent years. Studies by Zhang et al (2017) show a significant boom in publication growth, especially from 2010 to 2015 in China, as China has become the main emitter of CO2. This is corroborated by other publications in the same area of study (Guan et al. 2012; Liu et al. 2013; Wang, 2013; Guan et al. 2014; Liu et al. 2015).

The conclusions presented in the studies by Chen et al. (2016) attest to this assertion by presenting an overview of the development of Chinese energy and fuel research, especially by using this information for policy formulation and impact assessment in past resource allocation decisions to develop energy policies and strategies for the near future.

Table 8. Top ten countries with the most publications

\begin{tabular}{clcc}
\hline Ranking & Countries / Regions & Records & \% of 4610 \\
\hline $1^{\circ}$ & Peoples R China & 926 & 20,087 \\
$2^{\circ}$ & USA & 875 & 18,980 \\
$3^{\circ}$ & Italy & 280 & 6,074 \\
$4^{\circ}$ & England & 270 & 5,857 \\
$5^{\circ}$ & Iran & 268 & 5,813 \\
$6^{\circ}$ & Canada & 262 & 5,683 \\
$7^{\circ}$ & Spain & 237 & 5,141 \\
$8^{\circ}$ & France & 218 & 4,729 \\
$9^{\circ}$ & India & 212 & 4,599 \\
$10^{\circ}$ & South Korea & 201 & 4,360 \\
$22^{\circ}$ & Brazil & 72 & 1,562 \\
\hline
\end{tabular}

The difference between Brazil, occupying 22nd position and China in the first position is 18.53 percentage points. Put another way, China has exactly $1,186.11 \%$ of publications compared to Brazil. Corroborates the fact that the People's Republic of China appears first in the ranking with the fact that among the ten authors with the largest number of publications, six (60\%) are linked to institutions located in China. On the other hand, although 
the United States occupies the second position in the ranking, none of the first ten authors has any connection with American educational and / or research institutions.

Importantly, China cooperated with 75 countries in the field of energy and fuels, being among the eleven countries with the most international collaboration between 1993 and 2012. The collaboration number was over 100 published documents. The total number of cooperatively produced papers in these countries represented $76.7 \%$ of the total documents. The United States was China's most important cooperative partner $(1433,45.4 \%)$, followed by Japan $(498,15.8 \%)$, the United Kingdom $(398,12.6 \%)$ and Canada $(384,12.2 \%)$. The top five countries with international collaboration with China were also the world's five most energy and fuel producing countries [39]. These findings indicate that China has worked closely with Western developed countries and countries / territories that have special relations with Western developed countries (Chen et al. 2016).

\subsection{Journals}

In terms of journal performance, Energies was the most productive journal, with a total of 224 articles, followed by Applied Energy (185 articles) and Energy (166 articles). Compared to the studies by Guozhu et al. (2015), the Energy journal was in third position and the Journal of Cleaner Production in 12th position, whereas in this study the same journal occupies the sixth position. Table 9 presents the ten journals with the greatest contribution in the research area under study.

Table 9. Top ten contributing journals in research-related studies

\begin{tabular}{clcc}
\hline Ranking & Journal & Pubs & \% \\
\hline $1^{\circ}$ & Energies & 224 & 4,859 \\
$2^{\circ}$ & Applied Energy & 185 & 4,013 \\
$3^{\circ}$ & Energy & 166 & 3,601 \\
$4^{\circ}$ & Ieee Transactions On Smart Grid & 154 & 3,341 \\
$5^{\circ}$ & Energy Conversion and Management & 121 & 2,625 \\
$6^{\circ}$ & Journal of Cleaner Production & 98 & 2,126 \\
$7^{\circ}$ & Energy and Buildings & 92 & 1,996 \\
$8^{\circ}$ & Ieee Transactions On Vehicular Technology & 82 & 1,779 \\
$9^{\circ}$ & Ieee Access & 81 & 1,757 \\
$10^{\circ}$ & Energy Policy & 69 & 1,497 \\
\hline
\end{tabular}

Similarly, in the results presented by Chen et al. (2016), the periodicals in common as "Applied Energy", which in this study occupies the second position, in that occupies the ninth position. "Energy" (third in the ranking) occupies the tenth position, "Energy Conversion and Management" (6th position) and the journal "Energy and Buildings", the fourteenth position. Finally, the "Energy Policy", which is the last placed here, occupies the 12th position in Chen et al. (2016), a difference of two positions.

Compared to the studies by Geng et al. (2017), five journals appear in common, occupying the following positions: Energy Policy (1st); Energy and Buildings (2nd); Applied Energy (5th); Energy (6th); Journal of Cleaner Production (9th).

\subsection{General Reports}

The $\mathrm{h}$ index, also known as the Hirsch index, is defined according to the following scenario: A research unit has the index $h$ if $h$ of its publications have at least $h$ citations and the other publications have no more than $h$ citations (Waltman, 2016).

Waltman (2016) points out that the $\mathrm{h}$ index was introduced in 2005 (Hirsch, 2005) and quickly became very popular. For the purpose of this study, no detailed discussion of the literature on the $h$ index and its variants is provided. However, some basic and preliminary studies are presented if the reader wants to delve into the subject (Alonso et al., 2009; Panaretos and Malesios, 2009; Egghe, 2010; Norris and Oppenheim, 2010).

Using the h-index to evaluate an author's impact is not necessarily without criticism. Bornmann and Daniel (2009) argue that this is a key index question of the fact that how informative it is as a measure of a researcher's 
performance because the "researcher publication record usually contains some highly cited articles and many rarely cited". Conn (2010) warned that the $\mathrm{h}$ index could not be used to compare authors from different disciplines, nor was it an accurate indicator for new authors. Table 10 presents the overall citation report from the Web of Science Core Collection - WoS.

Table 10. Web of Science Core Collection General Report - WoS

\begin{tabular}{ccccccc}
\hline $\mathbf{1}$ & $\mathbf{2}$ & $\mathbf{3}$ & $\mathbf{4}$ & $\mathbf{5}$ & $\mathbf{6}$ & $\mathbf{7}$ \\
\hline $\begin{array}{c}\text { Total } \\
\text { publications }\end{array}$ & $\begin{array}{c}\text { Sum of } \\
\text { citations }\end{array}$ & $\begin{array}{c}\text { Sum of } \\
\text { citations } \\
\text { without } \\
\text { self-citations }\end{array}$ & $\begin{array}{c}\text { Articles that } \\
\text { cited }\end{array}$ & $\begin{array}{c}\text { Articles that } \\
\text { cited without } \\
\text { self-citations }\end{array}$ & $\begin{array}{c}\text { Average } \\
\text { citations per } \\
\text { item }\end{array}$ & h-index \\
\hline 4,610 & 86,224 & 76,591 & 54,778 & 52,284 & 18,70 & 111 \\
\hline
\end{tabular}

Table 11 presents more broadly the descriptive characteristics of each item mentioned in Table 8 . Thus, a better understanding of the criteria investigated in the set of citations extracted from the platform is possible.

The h-index (h index), which at this moment refers to all publications, refers to the average number of publications in the period. The h-index is a tool that measures researcher productivity and impact. Thus, the index $\mathrm{h}$ of a researcher is obtained by the number of articles published by him and which have citations in number or greater than this number (Hirsch, 2005).

Some studies pointed to limitations of the $\mathrm{h}$ index, which led authors such as Egghe (2006) to develop a variation of the $\mathrm{h}$ index, called the $\mathrm{g}$ index ( $\mathrm{g}$-index). According to the author, a set of papers has index $\mathrm{g}$ if $\mathrm{g}$ is the highest grade, so that the main articles together have at least $\mathrm{g}^{2}$ citations.

The e-index adds more precision in the analysis of the authors' production, especially because it has a greater range than the others. In addition, e-index is a necessary complement to h-index, especially to evaluate the most cited authors or to compare more precisely the scientific production of a group of authors (Zhang, 2009).

Table 11. Descriptive characteristics of each WoS platform item

\begin{tabular}{cl}
\hline Number & Description \\
\hline 1 & Total articles extracted after setting search criteria \\
2 & Total number of citations for all items in result set \\
3 & $\begin{array}{l}\text { Total number of citations, but with citation of other items in the unposted citations report } \\
\text { Total number of articles that cited. Citation articles mentioned one or more items in the citation } \\
\text { report }\end{array}$ \\
5 & $\begin{array}{l}\text { Total number of citing articles, and those citing articles that also appear in the citation report have } \\
\text { been removed }\end{array}$ \\
6 & $\begin{array}{l}\text { Average number of articles that cited for all items in the result set. This is the sum of the count of the } \\
\text { number of citations divided by the number of results in the set } \\
\text { This field displays the h-index count and is based on a list of publications sorted in descending order } \\
\text { by the number of citations count. An index of h means that there are h articles in which each has been } \\
\text { cited at least } h \text { times. H-index is based on the range of years of your product subscription and } \\
\text { selected stipulated time. Source items that are not part of your subscription will not be factored into } \\
\text { the calculation }\end{array}$ \\
\end{tabular}

\section{Conclusion}

The study aimed to analyze the publications cataloged on the Web of Science (WoS) using the keyword "Energy Manag *". Bibliometric was used as a methodological technique. The time frame was from 1999 to 2019, being initially measured 5,512 documents. We chose to include only articles of the type "articles", so this number was reduced to 4,610 papers. 
The analysis showed that there was a significant increase in publications in the field of study from 2007, with a predominance of articles published in the English language, with Spanish being third, very distant from the first. WoS categories with the highest participation were "Energy Fuels" and "Engineering Electrical Electronic" with $36,519 \%$ and 32,843\%, respectively. Regarding funding agencies, firstly the National Natural Science Foundation of China (Chinese) followed by the National Science Foundation NSF (American).

Of the ten authors with the largest number of publications, six are linked to educational / research institutions located in China. As for the countries with the largest number of publications, China ranks first in the ranking and soon after the United States. Brazil occupies the twenty-second position in this ranking. Of the ten journals with the largest number of publications, the first five are in the triple digits, being "Energies" (224); Applied Energy (185); "Energy" (166); "IEEE Transactions On Smart Grid" (154); and "Energy Conversion and Management" (121). The overall h-index index of all publications is 111 while the $\mathrm{h}$-index index of the ten authors occupying the ranking of publications h-index is 40 .

Compared to some similar studies, it is observed that China has shown a significant growth in the number of publications. Nevertheless, this point can generate a future research agenda by analyzing the exclusively Chinese publishing scenario.

\section{References}

Alonso, S., Cabrerizo, F. J., Herrera Viedma, E., \& Herrera, F. (2009). H-Index: A review focused in its variants, computation and standardization for different scientific fields. Journal of Informetrics, 3(4), 273-289. https://doi.org/10.1016/j.joi.2009.04.001

Antunes, P., Carreira, P., \& Silva, M. M. (2014). Towards an energy management maturity model. Energy Policy, 73, 803-814. https://doi.org/10.1016/j.enpol.2014.06.011

Baethge, C. (2008). Publish Together or Perish: The Increasing Number of Authors per Article in Academic Journals Is the Consequence of a Changing Scientific Culture. Some Researchers Define Authorship Quite Loosely. Dtsch Arztebl International, 105(20), 380-383. https://doi.org/10.3238/arztebl.2008.0380

Bornmann, L., \& Daniel, H. D. (2009). The state of $\mathrm{h}$ index research. Is the $\mathrm{h}$ index the ideal way to measure research performance? EMBO Report, 10(1), 2-6. https://doi.org/10.1038/embor.2008.233

Brasil. Ministério de Minas e Energia (MME). (2011). Plano Nacional de Eficiência Energética-Premissas e Diretrizes Básicas. Versão 18 out 2011. MME.

Camargo, J. R. K. R., \& Coeli, C. M. (2012). Múltipla autoria: crescimento ou bolha inflacionária? Revista de Saúde Pública, 46(5), 894-900. https://doi.org/10.1590/S0034-89102012000500017

Campomar, M. C. (2005). Pesquisa em marketing e seus problemas versus pesquisa de marketing. Anais... XXIX EnANPAD, Brasília-DF.

Cardoso, R. L., Mendonça Neto, O. R., Riccio, E. L., \& Sakata, M. C. G. (2005). Pesquisa científica em contabilidade entre 1990 e 2003. Revista de Administração de Empresas, 5(1). https://doi.org/10.1590/S0034-75902005000200004

Carvalho, M. F. A. M. F. (2013). Eficiência energética - a $4^{a}$ energia a importância das cidades para a eficiência energética - os casos das cidades do Porto e Estocolmo. Dissertação (Mestrado). Universidade Católica Portuguesa. Faculdade de Economia e Gestão. Portugal.

Chen, H. Q., Wang, X., He, L., Chen, P., Wan, Y., Yang, L., \& Jiang, S. (2016). Chinese energy and fuels research priorities and trend: A bibliometric analysis. Renewable and Sustainable Energy Reviews, 58, 966-975. https://doi.org/10.1016/j.rser.2015.12.239

Conn, V. S. (2010). Scientific impact considered. Western Journal of Nursing Research, 32(5), 575-577. https://doi.org/10.1177/0193945910365659

Cooper, D. R., \& Schindler, P. S. (2016). Business Research Methods. Twelfth Edition. New York, McGraw-Hill/Irwin.

Cristino, T. M., \& Faria Neto, A., \& Costa, A. F. B. (2018). Energy efficiency in buildings: analysis of scientific literature and identification of data analysis techniques from a bibliometric study. Scientometrics, 114(3), 1275-1326. https://doi.org/10.1007/s11192-017-2615-4

Croucher, M. (2011). Potential problems and limitations of energy conservation and energy efficiency. Energy Policy, 39, 5795-5799. https://doi.org/10.1016/j.enpol.2011.07.011 
De Bakker, F. G., Groenewegen, P., \& Den Hond, F. (2005). A bibliometric analysis of 30 years of research and theory on corporate social responsibility and corporate social performance. Business \& Society, 44(3), 283-317. https://doi.org/10.1177/0007650305278086

De Bellis, N. (2009). Bibliometrics and citation analysis: from the science citation index to cybermetrics. United States of America, 2009. https://doi.org/10.1002/asi.21181

Du, H. B., Wei, L. X., Brown, M. A., Wang, Y. Y., \& Shi, Z. (2013). A bibliometric analysis of recent energy efficiency literatures: an expanding and shifting focus. Energy Efficiency, 6(1), 177-190. https://doi.org/10.1007/s12053-012-9171-9

Du, M., Wang, B., \& Zhang, N. (2018). National research funding and energy efficiency: Evidence from the National Science Foundation of China. Energy Policy, 120, 335-346. https://doi.org/10.1016/j.enpol.2018.05.058

Duque, O. E. J., Cervera, T. A., \& Rodríguez, R. C. (2006). A bibliometric analysis of models measuring the concept of perceived quality in providing internet service. Innovar: Revista de Ciencias Administrativas y Sociales, 16(28), 223-243.

Egghe, L. (2006). Theory and practice of the g-index. Scientometrics, 69(1), 131-152. https://doi.org/10.1007/s11192-006-0144-7

Egghe, L. (2010). The Hirsch index and related impact measures. Annual Review of Information Science and Technology, 44(1), 65-114. https://doi.org/10.1002/aris.2010.1440440109

Epstein, R. J. (1993). Six authors in search of a citation: villains or victims of the Vancouver convention? The BMJ Journal, 306(6880), 765-767. https://doi.org/10.1136/bmj.306.6880.765

Fillipini, M., \& Hunt, L. C. (2015). Measurement of energy efficiency based on economic foundations. Energy Economics, 52(S5-S16). https://doi.org/10.1016/j.eneco.2015.08.023

Fink, A. (2005). Conducting Research Literature Reviews: from Paper to the Internet. SAGE Publications, Thousand Oaks.

Geng, Y., Chen, W., Liu, Z., Chiu, A. S. F., Han, W., Liu, Z., ... Cui, X. (2017). A bibliometric review: Energy consumption and greenhouse gas emissions in the residential sector. Journal of Cleaner Production, 159, 301-316. https://doi.org/10.1016/j.jclepro.2017.05.091

Gil, A. C. (2010). Como elaborar projeto de pesquisa. São Paulo: Atlas.

Goldemberg, J. (2000). Pesquisa e desenvolvimento na área de energia. São Paulo em Perspectiva, 14(3), 91-97. https://doi.org/10.1590/S0102-88392000000300014

Guan, D., Klasen, S., Hubacek, K., Feng, K., Liu, Z., He, K., ... Zhang, Q. (2014). Determinants of stagnating carbon intensity in China. Nat Clim Change, 4, 1017-1023. https://doi.org/10.1038/nclimate2388

Guan, D., Liu, Z., Geng, Y., Lindner, S., \& Hubacek, K. (2012). The gigatonne gap in China's carbon dioxide inventories. Nat Clim Change, 2, 672-675. https://doi.org/10.1038/nclimate1560

Guozhu, M., Xi, L., Huibin, D., Jian Z., \& Linyuan, W. (2015). Way forward for alternative energy research: A bibliometric analysis during 1994-2013. Renewable and Sustainable Energy Reviews, 48, 276-286. https://doi.org/10.1016/j.rser.2015.03.094

Gustav, R., Anne, H., Thomas, F., Christian, P., Felipe, T., \& Reinhard, H. (2008). Potentials and prospects for renewable energies at global scale. Energy Policy, 36(11), 4048-4056. https://doi.org/10.1016/j.enpol.2008.06.029

Hair, J. F. J., Babin, B., Money, A. H., \& Samouel, P. (2005). Fundamentos de métodos de pesquisa em administração. Porto Alegre: Bookman.

Hart, C. (1998). Doing a Literature Review - Releasing the Social Science Research Imagination. SAGE Publications, London.

Henderson M., Shurville, S., \& Fernstrom, K. (2009). The quantitative crunch: the impact of bibliometric research quality assessment exercises on academic development at small conferences. Campus-Wide Inf Syst, 26(3), 149-67. https://doi.org/10.1108/10650740910967348

Hirsch, J. E. (2005). An index to quantify an individual's scientific research output. PNAS, 102(46), 16569-16572. https://doi.org/10.1073/pnas.0507655102 
Huang, C., Su, J., Zhao, X. Y., Sui, J. G., Ru, P., Zhang, H. W., \& Wang, X. (2012). Government funded renewable energy innovation in China. Energy Policy, 51, 121-127. https://doi.org/10.1016/j.enpol.2011.08.069

Huang, C., Yang, C., \& Su, J. (2018). Policy change analysis based on "policy target-policy instrument" patterns: a case study of China's nuclear energy policy. Scientometrics, 117(2), 1081-1114. https://doi.org/10.1007/s11192-018-2899-z

International Energy Agency (IEA). (2015). Energy and climate change. Retrieved November 19, 2019 from https://www.iea.org/publications/freepublications/publication/WEO2015SpecialReportonEnergyandClimate Change.pdf

Ismail, S., Nason, E., Marjanovic, S., \& Grant, J. (2009). Bibliometrics as a Tool for Supporting Prospective R\&D Decision-making in the Health Sciences. RAND Corporation, 78.

Kern, F., \& Smith, A. (2008). Restructuring energy systems for sustainability? Energy transition policy in the Netherlands. Energy Policy, 36(11), 4093-4103. https://doi.org/10.1016/j.enpol.2008.06.018

Lafontaine, A., Beucher, O., Costa, E., \& Osmanagic, M. (2010). Delivering on Energy: An overview of activities by UN-Energy and its members. New York: United States.

Levsky, M. E., Rosin, A., Coon, T. P., Enslow, W. L., \& Miller, M. A. (2007). A descriptive analysis of authorship within medical journals, 1995-2005. South Med. Journal, 100(4), 371-375. https://doi.org/10.1097/01.smj.0000257537.51929.4b

Liu, Z., Guan, D., Crawford-Brown, D., Zhang, Q., He, K., \& Liu, J. (2013). Energy policy: a low-carbon road map for China. Nature, 500, 143-145. https://doi.org/10.1038/500143a

Liu, Z., Guan, D., Wei, W., Davis, S. J., Ciais, P., \& Bai, J. et al. (2015). Reduced carbon emission estimates from fossil fuel combustion and cement production in China. Nature, 524, 335-338. https://doi.org/10.1038/nature14677

May, G., Stahi, B., Taisch, M., \& Kiritsis, D. (2017). Energy management in manufacturing: From literature review to a conceptual framework. Journal of Cleaner Production, 167(20), 1464-1489. https://doi.org/10.1016/j.jclepro.2016.10.191

Merigó, J. M., Gil-Lafuente, A. M., \& Yager, R. R. (2015). An overview of fuzzy research with bibliometrics indicators. Applied Soft Computing, 27, 420-433. https://doi.org/10.1016/j.asoc.2014.10.035

Narayanan, K. V., \& Natarajan, E. (2007). Experimental studies on cofiring of coal and biomass blends in India. Renewable Energy, 32(15), 2548-58. https://doi.org/10.1016/j.renene.2006.12.018

Norris, M., \& Oppenheim, C. (2010). The h-index: A broad review of a new bibliometric indicator. Journal of Documentation, 66(5), 681-705. https://doi.org/10.1108/00220411011066790

Oikonomou, V., Becchis, F., Steg, L., \& Russolillo, D. (2009). Energy saving and energy efficiency concepts for policy making. Energy Policy, 37, 4787-4796. https://doi.org/10.1016/j.enpol.2009.06.035

Olatomiwa, L., Mekhilef, S., Ismail, M. S., \& Moghavvemi, M. (2016). Energy management strategies in hybrid renewable energy systems: A review. Renewable and Sustainable Energy Reviews, 62, 821-835. https://doi.org/10.1016/j.rser.2016.05.040

Panaretos, J., \& Malesios, C. (2009). Assessing scientific research performance and impact with single indices. Scientometrics, 81(3), 635-670. https://doi.org/10.1007/s11192-008-2174-9

Patrik, S., \& Thomas, S. (2007). Empirical challenges in the use of learning curves for assessing the economic prospects of renewable energy Technologies. Renewable Energy, 32(15), 2559-2578. https://doi.org/10.1016/j.renene.2006.12.007

Perin, M. G., Froemming, L. M. S., Luce, F. B., Sampaio, C. H., Beber, S. J. N., \& Trez, G. (2000). Análise da qualidade dos artigos científicos da área de marketing no Brasil: as pesquisas survey na década de 90. Revista de Administração Contemporânea, 4(3), 201-219. https://doi.org/10.1590/S1415-65552000000300011

Pritchard, A. (1969). Statistical bibliography or bibliometrics? Journal of Documentation, 25(4), 348-349. https://doi.org/10.1108/eb026482

Raupp, F. M., Beuren, I. M. (2008). Metodologia da Pesquisa Aplicável as Ciências Sociais. In BEUREN, I. M. (Ed.), Como Elaborar Trabalhos Monográficos em Contabilidade: Teoria e Prática. São Paulo: Atlas, 2008. 
Richardson, R. J., Peres, J. A. S., Wanderley, J. C. V., Correia, L. M., \& Peres, M. H. M. (1999). Pesquisa social: métodos e técnicas (3rd ed.). São Paulo: Atlas.

Sepúlveda, J. (2016). Evaluation of research in the field of energy efficiency and MCA methods using publications databases. International Journal of Environmental, 10(2), 1-4.

Shaban, S., \& Aw, T, C. (2009). Trend towards multiple authorship in occupational medicine journals. J Occup Med Toxicol. 4(3). https://doi.org/10.1186/1745-6673-4-3

Tasca, J. E., Ensslin, L., Ensslin, S. R., \& Alves, M. B. M. (2010). An approach for selecting a theoretical framework for the evaluation of training programs. Journal of European Industrial Training, 34(7), 631-655. https://doi.org/10.1108/03090591011070761

Tranfield, D., Denyer, D., \& Smart, P. (2003). Towards a methodology for developing evidence-informed management knowledge by means of systematic review. Br. J. Manag., 14(3), 207-222. https://doi.org/10.1111/1467-8551.00375

Tylock, S. M., Seager, T. P., Snell, J., Bennett, E. R., \& Sweet, D. (2012). Energy management under policy and technology uncertainty. Energy Policy, 47, 156-163. https://doi.org/10.1016/j.enpol.2012.04.040

Venuto, N. M., \& De Muylder, C. F. (2010). Competências: um estudo bibliométrico dos anais do EnANPAD de 2008 e 2009. Anais... Encontro Nacional de Engenharia de Produção - XXX EnEGEP. São Carlos, SP.

Vieira, F. G. D. (2003). Narciso sem espelho: a publicação brasileira de marketing. RAE - Revista de Administração de Empresas, 43(1), 81-90. https://doi.org/10.1590/S0034-75902003000100009

Waltman, L. (2016). A review of the literature on citation impact indicators. Journal of Informetrics, 10(2), 365-391. https://doi.org/10.1016/j.joi.2016.02.007

Wang, Q. (2013). China has the capacity to lead in carbon trading. Nature, 493(7432), 273. https://doi.org/10.1038/493273a

Wuchty, S., Benjamin, F. J., \& Uzzy, B. (2007). The increasing dominance of teams in production of knowledge. Science Express, 316(5827), 1036-1039. https://doi.org/10.1126/science.1136099

Zhang, B., Bi, J., Fan, Z., Yuan, J., \& Ge, Z. (2008). Eco-efficiency analysis of industrial system in China: a data envelopment analysis approach. Ecological. Economics, 68(1), 306-316. https://doi.org/10.1016/j.ecolecon.2008.03.009

Zhang, C. T. (2009). The e-Index, complementing the h-Index for excess citations. PLoS ONE, 4(5), 1-4. https://doi.org/10.1371/journal.pone.0005429

Zhang, W., \& Yang, S. (2013). The influence of energy consumption of China on its real GDP from aggregated and disaggregated viewpoints. Energy Policy, 57, 76-81. https://doi.org/10.1016/j.enpol.2012.10.023

Zhang, Z., Zhao, Y., Su, B., Zhang, Y., Wang, S., Liu, Y., \& Li, H. (2017). Embodied carbon in China's foreign trade: An online SCI-E and SSCI based literature review. Renewable and Sustainable Energy Reviews, 68, 492-510. https://doi.org/10.1016/j.rser.2016.10.009

Zhao Z. Y., Hu, J., \& Zuo, J. (2009). Performance of wind power industry development in China: a diamond model study. Renewable Energy, 34(12), 2883-2891. https://doi.org/10.1016/j.renene.2009.06.008

Zhao, Z. Y., Zuo, J., Fan, L. L., \& Zillante, G. (2011). Impacts of renewable energy regulations on the structure of power generation in China-a critical analysis. Renewable Energy, 36(1), 24-30. https://doi.org/10.1016/j.renene.2010.05.015

Zhenxing, J., \& Jing, W. Y. L. (2007). Design of energy efficiency supervision system for large-scale public buildings. Journal HV\&AC, 8, 19-22.

\section{Copyrights}

Copyright for this article is retained by the author(s), with first publication rights granted to the journal.

This is an open-access article distributed under the terms and conditions of the Creative Commons Attribution license (http://creativecommons.org/licenses/by/4.0/). 